\title{
STUDENTS' ATTITUDES TOWARDS NUCLEAR ENERGY: RUSSIAN AND ITALIAN EXPERIENCE
}

\author{
ANZHELIKA KARAEVA ${ }^{1}$, ELENA R. MAGARIL ${ }^{1}$ \& ELENA CRISTINA RADA ${ }^{2,3}$ \\ ${ }^{1}$ Department of Environmental Economics, Ural Federal University, Russian Federation \\ ${ }^{2}$ Department of Civil, Environmental and Mechanical Engineering, University of Trento, Italy \\ ${ }^{3}$ Department of Theoretical and Applied Science, University of Insubria, Italy
}

\begin{abstract}
Nowadays, the energy sector faces a lot of challenges because of environmental issues, the potential depletion of fossil fuels in the future, problems of technological development, etc. Despite the fact that alternative energy is a key factor of the energy sector's development, it still has several controversial questions, and one of them is "to what extent is nuclear energy safe for the world?" As a consequence, public acceptability has a role to play as it significantly affects the way nuclear energy should be developed in the next decades. In this paper, we provide the main results of the research made in December 2018 in Italy and Russia on students' attitude towards nuclear energy and its development in their homelands. The research method is a questionnaire which was carried out at the University of Trento, Italy, and at Ural Federal University, Russia. According to the given results, most of the students from both countries do not have a negative perception of nuclear energy. However, the opinions on its development in Italy and Russia are completely different: Russian students support the government's energy program in which nuclear energy is one of the most promising trends for the future, whereas Italian students do not accept the possibility that nuclear energy could come back into the Italian energy sector.

Keywords: nuclear energy, public acceptability, environment, green energy.
\end{abstract}

\section{INTRODUCTION}

Currently, the energy sector is undergoing significant changes: more and more countries are striving to switch to "green" energy, thereby reducing the level of anthropogenic impact on the environment. At the same time, circular economy is giving the energy sector a different role [1], [2]. In a number of countries, nuclear energy is characterized as the energy of the future and referred to as "green". According to the European Environmental Energy report [3], this area of energy has great prospects and may become a key factor in resolving the fuel and energy crisis in the future. The fundamentals of the nuclear energy generation are well-known, and pros and cons of its application are widely discussed [4]-[7]. The nuclear power generation demonstrates the highest level of environmental characteristics and the nuclear power plants give a high power output [8]. Moreover, the final cost of generated energy is much cheaper than energy produced by using fossil fuels. However, the lessons of accidents in the past, such as Chernobyl and Fukushima, moved the issues of safety and security at the nuclear power plants to the forefront, which contributed to the rapid development of new safety technologies [9] and raised requirements for personnel skills [10].

According to the concept of sustainable development, it is necessary that nuclear power meets a number of criteria, which can generally be divided into political, social, environmental and welfare [11]. The group of social criteria can be called one of the most controversial and constraining the development of the industry in question. Due to the negative attitude of the population and the potential risks in a number of states, there are significant difficulties in its development [12]. For example, the governments of most developed countries, including Germany, Italy, Austria, the Czech Republic, and others, have suspended or completely abandoned the use of nuclear energy for peaceful purposes. The 
main reason for failure is the potential risks that can cause irreparable harm to humanity and the environment and the negative attitude of the population [13].

Public opinion, in this case, directly correlates with the attitude of the government on the use of nuclear energy. More than $40 \%$ of US (which is one of the leaders of nuclear energy in the world) residents support the construction of new nuclear power plants (NPP) even after the Fukushima accident that occurred in 2013 [14], while less than 7\% of German citizens showed a positive attitude towards the resumption of their operation and the start of construction of new NPP [15]. It should be noted that Germany decommissioned all nuclear reactors immediately after the Fukushima accident in 2013.

Public opinion is a serious development barrier that can significantly restrain the development of technology and energy in general. The study [16] also revealed several components from which public opinion can vary significantly within the framework of a given topic: the level of awareness of the main aspects of the use of a particular type of energy, its perception by the population, the presence of fears and age.

In addition, there is a construal level theory (CLT), which is the most relevant nowadays when considering issues related to public opinion and nuclear energy [17]. In the framework of CLT, it is assumed that the greater the distance between the subject of perception and man, the more abstract the image is formed in human thinking [18]. So, for example, people with the smallest distance (low-distant) to nuclear power, are inclined to support the state in matters of its development, whereas people, living in a state that does not support nuclear power and thus being "distant" from it, are convinced in a high risk of its use [19]. The human psyche is not able to assess all the risks of a process or phenomenon that is physically distant from an individual.

CLT clearly demonstrates that the level of public awareness in various aspects of energy is a key factor in its development as a whole. Currently, the relationship between the level of development of nuclear energy, state policy in this matter and public opinion is not well understood, especially among young people aged 21 to 35 years. The low level of elaboration of the problem determined the main goal of the research - studying the attitude of young people to nuclear energy in countries with different energy policies in order to identify the relationship between such factors as attitudes towards nuclear energy, risks, the level of state support in this matter and the awareness of the technical aspects of its use.

\section{CONDITION OF NUCLEAR ENERGY INDUSTRY IN RUSSIA AND ITALY}

Nowadays Italy is a leader in the development of renewable energy sources [20]. However, in the period from 1960s to 1980 s the Italian government actively encouraged the development of nuclear energy as well. Due to Chernobyl disaster at 1986 which had taken place at the territory of the modern Ukraine, Italian energy policy significantly changed. In Russia, the development of nuclear energy didn't stop, neither after the Chernobyl disaster nor after serious political reforms in 1990s.

\subsection{Nuclear energy industry in Russia}

The Russian Federation is one of the leaders in nuclear energy usage and its development. Moreover, Russian nuclear industry is highly interested in several projects which are being implemented abroad such as construction of nuclear power plants and their further operation. In the next few decades Russian companies are planning to construct and build up more than 20 nuclear reactors in India, Pakistan, Algeria etc. These projects are worth more than $\$ 133$ billion overall according to latest calculations made in 2017. Currently there are 35 operated nuclear reactors in Russia (Table 1). 
Table 1: Operating nuclear reactors in the Russian Federation [21].

\begin{tabular}{|l|c|c|c|c|}
\hline Reactor & $\begin{array}{c}\text { Type } \\
\text { V=PWR }\end{array}$ & Net MWe & $\begin{array}{c}\text { Commercial } \\
\text { operation }\end{array}$ & $\begin{array}{c}\text { Licensed to, or } \\
\text { scheduled close }\end{array}$ \\
\hline Balakovo 1 & V-320 & 988 & $5 / 86$ & 2043 \\
\hline Balakovo 2 & V-320 & 988 & $1 / 88$ & 2033 \\
\hline Balakovo 3 & V-320 & 988 & $4 / 89$ & 2049 \\
\hline Balakovo 4 & V-320 & 988 & $12 / 93$ & 2053 \\
\hline Beloyarsk 3 & BN-600 FBR & 560 & $11 / 81$ & 2025 \\
\hline Beloyarsk 4 & BN-800 FBR & 789 & $10 / 16$ & 2056 \\
\hline Bilibino 2-4 & LWG EGP-6 & $11 \times 3$ & $12 / 74-1 / 77$ & Dec 2021 \\
\hline Kalinin 1 & V-338 & 988 & $6 / 85$ & 2045 \\
\hline Kalinin 2 & V-338 & 988 & $3 / 87$ & 2047 \\
\hline Kalinin 3 & V-320 & 988 & $11 / 2005$ & 2065 \\
\hline Kalinin 4 & V-320 & 988 & $9 / 2012$ & 2072 \\
\hline Kola 1 & V-230 & 432 & $12 / 73$ & 2033 \\
\hline Kola 2 & V-230 & 411 & $2 / 75$ & 2029 \\
\hline Kola 3 & V-213 & 440 & $12 / 82$ & 2027 \\
\hline Kola 4 & V-213 & 440 & $12 / 84$ & 2039 \\
\hline Kursk 1 & RBMK & 971 & $10 / 77$ & 2022 \\
\hline Kursk 2 & RBMK & 971 & $8 / 79$ & 2024 \\
\hline Kursk 3 & RBMK & 971 & $3 / 84$ & 2029 \\
\hline Kursk 4 & RBMK & 925 & $2 / 86$ & 2031 \\
\hline Leningrad 2 & RBMK & 971 & $2 / 76$ & 2021 \\
\hline Leningrad 3 & RBMK & 971 & $6 / 80$ & 2025 \\
\hline Leningrad 4 & RBMK & 925 & $8 / 81$ & 2026 \\
\hline Leningrad II-1 & V-491 & 1085 & $10 / 2018$ & $2078 ?$ \\
\hline Novovoronezh 4 & V-179 & 385 & $3 / 73$ & 2032 \\
\hline Novovoronezh 5 & V-187 & 950 & $2 / 81$ & 2035 potential \\
\hline Novovoronezh II-1 $*$ & V-392M & 1114 & $2 / 2017$ & 2077 \\
\hline Smolensk 1 & RBMK & 925 & $9 / 83$ & 2028 \\
\hline Smolensk 2 & RBMK & 925 & $7 / 85$ & 2030 \\
\hline Smolensk 3 & RBMK & 925 & $1 / 90$ & 2050 \\
\hline Rostov 1 & V-320 & 990 & $3 / 2001$ & 2030 \\
\hline Rostov 2 & V-320 & 990 & $10 / 2010$ & 2040 \\
\hline Rostov 3 & V-320 & 1011 & $9 / 2015$ & 2045 \\
\hline Rostov 4 & V-320 & 1011 & $9 / 2018$ & \\
\hline Total: 35 & & & & \\
\hline & & & MWe & \\
\hline
\end{tabular}

Despite the fact that the level of nuclear energy development is considerably exceeds average point among other countries, the volume of its consumption is much lower in comparison to the fossil fuel usage. Fig. 1 provides the structure of primary energy consumption in Russia in 2017.

According to the Fig. 1, the large share in the primary energy consumption in Russia is oil and natural gas: $22 \%$ and $52 \%$ respectively, whereas the nuclear power share is only $7 \%$ - lower than coal consumption, which is $13 \%$.Most of all, nuclear power plants 


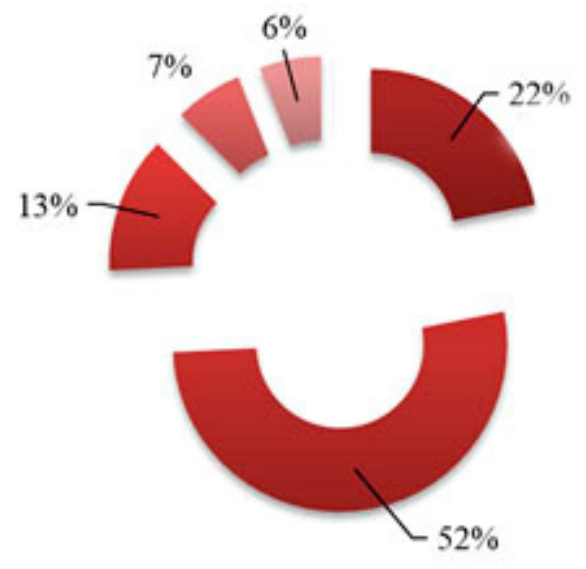

ail

= Natural Gas

- Coal

- Nuclear energy

$=$ Hydro electric

Renewables

Figure 1: Primary energy consumption by fuel in Russia, 2017 (based on data from World Nuclear Association [21]).

are mainly located in the Western part of Russia due to the significant difference in the level of development among regions, their financing and population density.

Russia is also a leader in the development and producing of fast neutron reactors. This type of reactors has favourable environmental performance as that type of reactors can reduce the total radiotoxicity of nuclear waste [22]. Moreover, it has a standpoint of involving uranium 238 in the fuel chain, which is a strategic solution to the problem of providing nuclear fuel.

\subsection{Nuclear energy industry in Italy}

Nuclear energy in Italy was developing since 1958 till 1990s. In this period, 4 nuclear power plants were constructed and operated. Their total capacity was around $1423 \mathrm{MW}$ (Table 2).

Table 2: Nuclear power plants operated in Italy since 1958 till the 1990s [23].

\begin{tabular}{|l|c|c|c|c|}
\hline Reactor & Model & Net MWe & First power & Shutdown \\
\hline Latina & GCR & $153^{\mathrm{h}}$ & $05 / 1963$ & $12 / 1987$ \\
\hline Garigliano & BWR & 150 & $01 / 1964$ & $03 / 1982$ \\
\hline $\begin{array}{l}\text { Enrico Fermi } \\
\text { (Trino Vercellese) }\end{array}$ & PWR & 260 & $10 / 1964$ & $07 / 1990$ \\
\hline Caorso & BWR & 860 & $05 / 1978$ & $07 / 1990$ \\
\hline $\begin{array}{l}\text { Montalto di Castro } \\
\text { (Alto Lazio) 1\&2 }\end{array}$ & BWR & 982 each & Cancelled & - \\
\hline Total operated (4) & & \multicolumn{3}{|c|}{1423 MWe } \\
\hline
\end{tabular}


The Chernobyl disaster was the main reason for nuclear power plants' shutdown. In 1987, Italian government held a national referendum on the destiny of nuclear energy's future. Most citizens voted against of its development. Currently, Italy doesn't produce nuclear energy, however it is possible to import nuclear energy from other producers and take part in their construction within foreign nuclear projects.

The structure of primary energy consumption in Italy is quite similar to the Russian one. Consumption of imported fossil fuels takes the first and second place: natural gas consumption is about $40 \%$, whereas oil consumption is $39 \%$. Renewable energy is in the third place in terms of total energy consumption (Fig. 2). Both countries mainly use natural gas as a primary energy source: $40 \%$ in Italy and $52 \%$ in Russia.

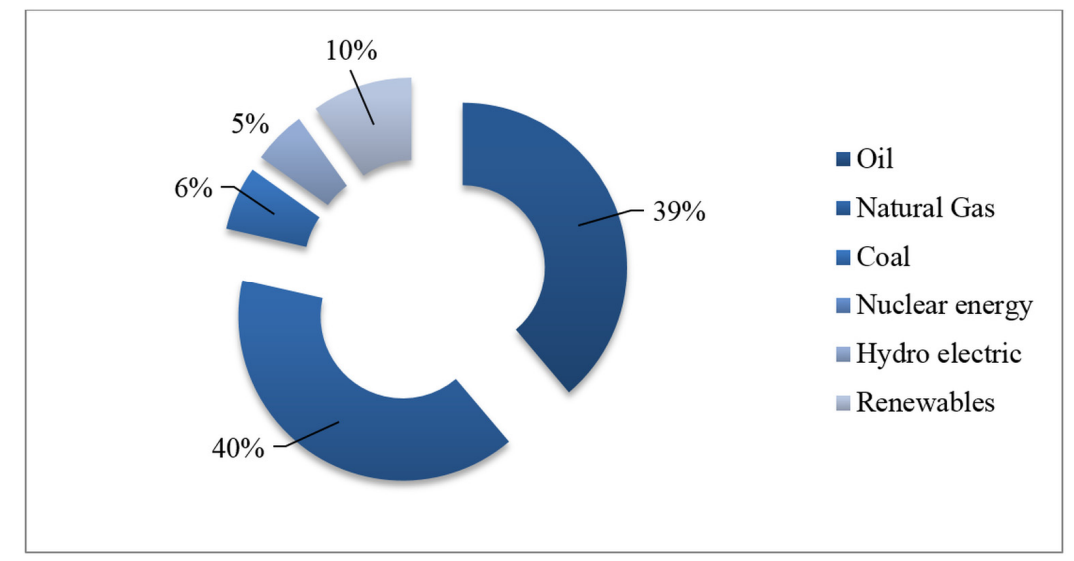

Figure 2: Primary energy consumption by fuel in Italy, 2017 (based on data from World Nuclear Association [23]).

It should be noted that the coal usage in Italy is significantly lower in comparison to Russia. Renewable energy in Russian primary energy consumption structure is less than 1\% that provides low level of its development, while nuclear energy consumption is more than 7\% (Fig. 1).

There is a completely different situation in Italy: while the generation of nuclear energy is absent, $10 \%$ of the total number of energy consumption is renewable energy sources, apart from hydroelectric.

\section{RESEARCH METHODS}

This research entails an international project studying students' attitude towards nuclear energy development. Authors carried out a survey in order to estimate the public acceptability of nuclear energy among young people of both counties. This paper analyses the questionnaire responses and provides crucial trends discovered within project study.

The survey was designed with aid of students of Ural Federal University: a technical section was made by the students of Power Engineering Institute and other section was provided by students of Graduate School of Economics and Management. Voluntary respondents were students of technical major studying at Ural Federal University named after the first president of Russia, B.N. Yeltsin (Ekaterinburg, Russia) and at University of Trento (Trento, Italy). The survey includes 8 multiply choice questions about different aspects of nuclear energy (Table 3). 
Table 3: The structure of survey.

\begin{tabular}{|c|c|}
\hline The question & Answer option \\
\hline $\begin{array}{l}\text { 1. In your opinion, does the construction of } \\
\text { nuclear power plants pose a potential risk to the } \\
\text { environment of the region you currently live in? }\end{array}$ & $\begin{array}{l}\text { 1) Yes, it does } \\
\text { 2) Possibly yes } \\
\text { 3) Possibly not } \\
\text { 4) No, it doesn't } \\
\text { 5) It is hard to answer }\end{array}$ \\
\hline $\begin{array}{l}\text { 2. In your opinion, could the nuclear energy be } \\
\text { the part of the "green" energy? }\end{array}$ & $\begin{array}{l}\text { 1) Yes, it does } \\
\text { 2) Possibly yes } \\
\text { 3) Possibly not } \\
\text { 4) No, it doesn't } \\
\text { 5) It is hard to answer }\end{array}$ \\
\hline $\begin{array}{l}\text { 3. What is the main benefit of producing the } \\
\text { nuclear energy? }\end{array}$ & $\begin{array}{l}\text { 1) Ecological safety } \\
\text { 2) Low expenses on producing } \\
\text { 3) Low expenses on distributing } \\
\text { 4) Effectiveness of energy supply } \\
\text { 5) Low level of usage of fossil fuels } \\
\text { 5) Long-term usage of nuclear } \\
\text { power plants } \\
\text { 6) Other (please, write you option) }\end{array}$ \\
\hline $\begin{array}{l}\text { 4. Do you support the government's attitude } \\
\text { towards the nuclear energy in the country you } \\
\text { currently live in? }\end{array}$ & $\begin{array}{l}\text { 1) Yes, I do } \\
\text { 2) No, I don't } \\
\text { 3) It is hard to answer }\end{array}$ \\
\hline $\begin{array}{l}\text { 5. What is the purpose of using the cooling tower } \\
\text { at nuclear power plants? }\end{array}$ & $\begin{array}{l}\text { 1) For releasing of toxic emissions } \\
\text { 2) For waste recycling } \\
\text { 3) For cooling water } \\
\text { 4) For heating nuclear fuel } \\
\text { 5) It is hard to answer }\end{array}$ \\
\hline $\begin{array}{l}\text { 6. What type of fuels is used at nuclear power } \\
\text { plants? }\end{array}$ & $\begin{array}{l}\text { 1) Uranium } \\
\text { 2) Radium } \\
\text { 3) Tritium } \\
\text { 4) Thorium } \\
\text { 5) Any radioactive substance }\end{array}$ \\
\hline 7. How to protect yourself from alpha-radiation? & $\begin{array}{l}\text { 1) To put on outwear } \\
\text { 2) To run away from radiation } \\
\text { source } \\
\text { 3) To hide behind the concrete wall } \\
\text { 4) To start using specific } \\
\text { medication } \\
\text { 5) It is hard to answer }\end{array}$ \\
\hline $\begin{array}{l}\text { 8. In your opinion, is a person exposed to } \\
\text { radiation dangerous? }\end{array}$ & $\begin{array}{l}\text { 1) Yes, he does } \\
\text { 2) No, he doesn't } \\
\text { 3) Depends on time of exposure } \\
\text { 4) Depends on type of radiation } \\
\text { 5) It is hard to answer }\end{array}$ \\
\hline
\end{tabular}


The survey includes several blocks that aids to not only reveal the attitude of students to nuclear energy, but also to check their level of awareness of the basic aspects of the use of this type of energy.

The first section (questions 1-4) was a collection of information about the general attitude of young people to nuclear energy.

The second section of the survey (questions 5-8) related to the basic theoretical aspects of nuclear energy (mainly, security and technological components).

The survey includes three main stages:

1. Carrying out the survey among Russian students within 15th December and 25th December 2018. Overall there were 62 respondents: 23 of them are students of Civil Engineering Department, 39 of them are students of Power Engineering Institute. Questionnaire method: online survey.

2. Carrying out the survey among Italian Students in the period from 21 st December to 23rd December 2018. There were 50 respondents from Department of Civil, Mechanical and Environmental Engineering. Questionnaire method: traditional survey.

3. Analysis of collected data using MS Office software and SPSS software.

The suggested survey is valid as a first stage of the general assessment of students' attitude towards nuclear energy in different countries and further may be more detailed developed and include additional questions.

\section{RESULTS AND DISCUSSION}

The study was based on the analysed data in order to confirm or refute the thesis about the correlation between the development of nuclear energy and public attitudes towards that in different countries (Italy and Russia). Both countries have completely opposite policies for the energy sector development: in Russia, nuclear energy shows an upward trend, while the Italian government has completely abandoned the construction and operation of nuclear power plants due to potential risks.

According to results of the first section, it might be concluded that the young people of both countries have more positive opinion about nuclear energy: more than half of all students surveyed do not consider nuclear energy dangerous (Table 4).

Table 4: The percentage of answers to the question "In your opinion, does the construction of nuclear power plants pose a potential risk to the environment of the region you currently live in?" (\%).

\begin{tabular}{|l|c|c|c|}
\hline \multirow{2}{*}{ Answer options } & \multicolumn{2}{|c|}{ Ural Federal University } & \multirow{2}{*}{$\begin{array}{c}\text { University of } \\
\text { Trento }\end{array}$} \\
\cline { 2 - 3 } & $\begin{array}{c}\text { Civil Engineering } \\
\text { Department }\end{array}$ & $\begin{array}{c}\text { Power Engineering } \\
\text { Institute }\end{array}$ & $22.00 \%$ \\
\hline Yes, it does & $30.43 \%$ & $2.56 \%$ & $4.00 \%$ \\
\hline Possibly yes & $17.39 \%$ & $7.69 \%$ & $38.00 \%$ \\
\hline Possibly no & $34.78 \%$ & $56.41 \%$ & $26.00 \%$ \\
\hline No, it doesn't & $0.00 \%$ & $30.77 \%$ & $10.00 \%$ \\
\hline It is hard to answer & $17.39 \%$ & $2.56 \%$ & \\
\hline
\end{tabular}


The most negative evaluation of nuclear energy was given by students of the Civil Engineering Department at Ural Federal University that might be caused by lack of knowledge in this area or the specifics of the study major. At the same time, despite the negative attitude of the Italian government, most students do not consider nuclear energy to be potentially perilous. Many students mentioned the point, that in case of minimizing the impact of the human factor during nuclear plants operation, nuclear power might be the main perspective of the world energy sector in near future.

Despite the positive attitude of young people, most of Trento University students believe that nuclear energy cannot be attributed to the green energy. Fig. 3 shows a radar chart with a ranking of the answers to the question "In your opinion, could the nuclear energy be the part of the 'green' energy?"

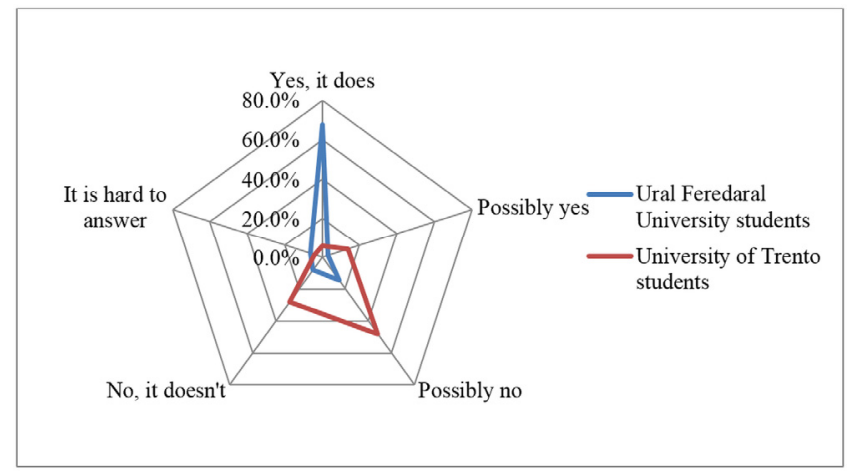

Figure 3: Petal chart of respondents' answers to the question about the possibility classifying nuclear energy as "green" one.

A possible reason for the significant difference in respondents' answer might be caused by fact that both the countries might have an absolutely different perception of nuclear energy.

Since the 1990s, the Italian government and the governments of other European countries (e.g. Austria, Czech Republic) have introduced a strict policy towards nuclear energy: in addition to the rejection of the construction and operation of nuclear power plants, the policy also has influenced the public attitude towards it and changed the public acceptability.

Students of the Russian University, on the contrary, believe that nuclear energy can be counted as a green one, and be part of environmentally safe energy sector, which is also due to the dissemination of information about the positive factors of its use (for instance, long-term perspective of its production and safety for the environment and people).

After the question about "green" energy, respondents had to answer the question related to the benefits of using nuclear power plants. According to the results, Russian students believe that the main benefit of nuclear energy is the environmental friendliness: more than $57 \%$ chose this answer, while the majority of Italian students mentioned the possibility of minimizing problems with the supply of electricity $(82 \%)$. This ratio of responses clearly demonstrates the attitude of the population of both countries to the energy sector and its structure at all. It should be noted that none of the total number of respondents chose the option of saving fossil fuels. The final question of the first block was about the attitude of students to the current state policy on nuclear energy (Fig. 4). Respondents from both 


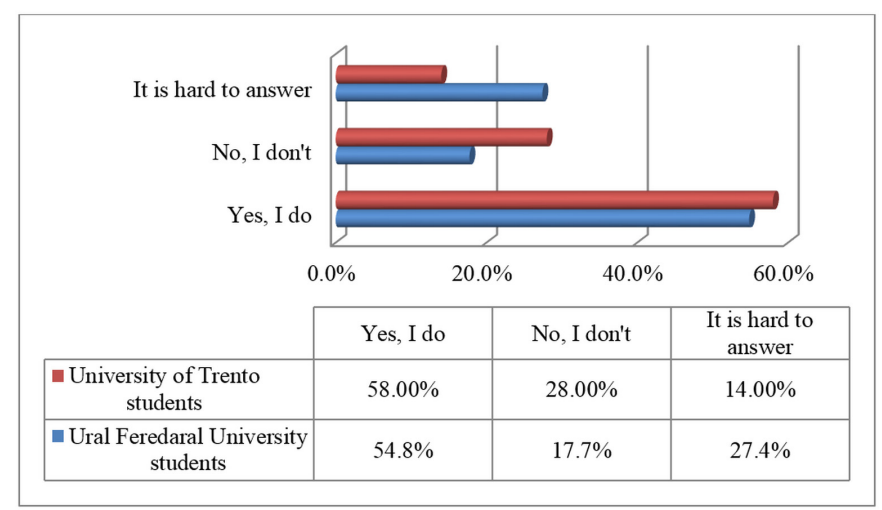

Figure 4: The ratio of students' answer about their approval of the governments' attitude to nuclear energy in the country they currently live in $(\%)$.

countries, approve of the government's policy according nuclear energy technologies, which is partially correlated with the answers to previous questions.

The second block of the survey (questions 5-8) related to the basic theoretical aspects of nuclear energy (mainly, security and technological components). Students from both countries demonstrated a high level of knowledge in the technical aspects of nuclear power plant's construction and operation. Fig. 5 shows the percentage of correct answers among students on questions $5-6$ of the survey.

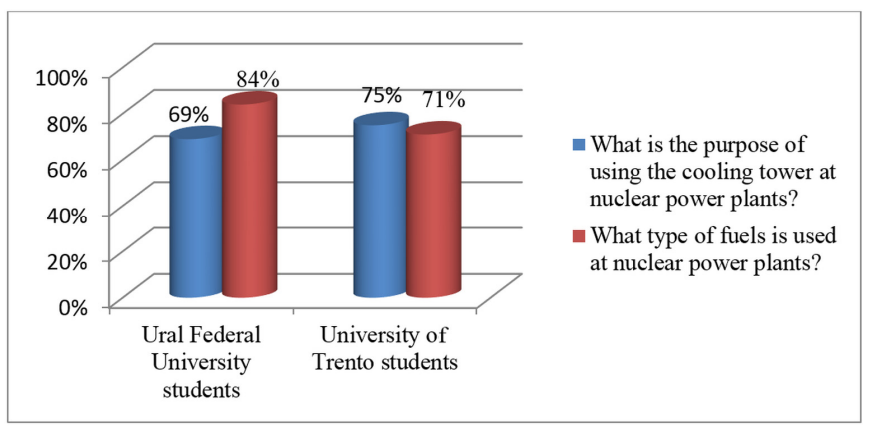

Figure 5: Correct students' answers to questions concerning technical aspects of nuclear plant's construction and operation (\%).

However, energy students or civil engineering students usually get the basics of nuclear power plant operation in some courses during the first two years of study. A positive sign is that more than $50 \%$ of students from Russia and Italy gave the correct answer to the first two questions of the second block (the main and only purpose of using the cooling tower at nuclear power plants is water cooling process and the fuel used at nuclear power plants is uranium, respectively).

The reverse trend is observed in the issues of compliance with safety measures in case of emergencies. Most students of Ural Federal University gave the correct answer to the 7th question of the survey "How to protect yourself against alpha radiation?" $(87.5 \%)$, whereas 
only $11 \%$ of Italian students are aware of the need to wear outerwear [24]. Moreover, $64 \%$ of Italian students preferred the answer "to run away from the radiation source". The main reason for this response ratio is that in Italy nuclear energy sector stopped its development more than 29 years ago, which causes the lack of need for training of this kind of skills. In Russia, this is a mandatory part of the subjects related to the safety of life.

The 8th question of the survey was "In your opinion, is a person exposed to radiation dangerous?". The main purpose of this question was to evaluate students' understanding of the effects of radiation on the human body. Table 5 shows the percentage of students in both countries who answered this question.

Table 5: The percentage of answers to the question "In your opinion, is a person exposed to radiation dangerous?".

\begin{tabular}{|l|c|c|}
\hline Answer option & Ural Federal University & University of Trento (DICAM) \\
\hline Yes, it does & $27.42 \%$ & $68.00 \%$ \\
\hline No, it doesn't & $51.61 \%$ & $4.00 \%$ \\
\hline Depends on time of exposure & $9.68 \%$ & $12.00 \%$ \\
\hline Depends on type of radiation & $1.61 \%$ & $2.00 \%$ \\
\hline It is hard to answer & $12.90 \%$ & $14.00 \%$ \\
\hline
\end{tabular}

Only $4 \%$ of Italian students gave the correct answer to the question, compared with $51.6 \%$ of Russian students: a person exposed to radiation is not a danger to others [25]. The possible reason for the results may coincide with the conclusion of the analysis of the answers to question 7. In general, a partial correlation was revealed between the use of nuclear power plants in a single state and the attitude of the population to this energy sector.

A significant part of Italian students, despite the relatively positive attitude to nuclear energy, supports the ban on the construction and operation of nuclear power plants in the Italian Republic, arguing for the need to develop renewable energy sources. Another identified feature is the high level of awareness of students of the University of Trento in the technological aspects of nuclear plant, but low knowledge in the field of security. Russian students living in the immediate vicinity of the Beloyarskaya Nuclear Power Plant demonstrated the relevant results: a positive attitude to nuclear energy, knowledge of the basic principles of its operation and safety.

According to a number of studies, the growth of loyalty to nuclear power in European countries was observed in 1990-2000 [26]. After this period, residents of most European countries have significantly changed their attitude, especially after the accident at the Fukushima nuclear power plant. In the course of the study conducted by the authors, it was expected that Italian students would demonstrate a low level of perception of nuclear energy, which would be due primarily to the attitude of the government [27]. Students of the University of Trento have no negative perceptions, as well as Russian students, but in general they do not support the initiative of construction and operation of nuclear power plants in territory of Italy. A possible reason may be that in Italy more attention is paid to renewable energy sources, which are actively developing in almost all parts of the country. The reason is public attitude: there are certain values for the maintenance of bioenergy among people, and nuclear energy is not perceived as a possible alternative. Moreover, another identified trend is the relationship between the age of respondents, their knowledge about nuclear power and their attitude to it. The authors found that young people, who, for the most part, possess 
a sufficient level of knowledge about nuclear power and are aware of the basic principles of nuclear power plants, are more loyal to the construction of additional nuclear power plants or power units to them. The revealed relationship between the level of knowledge and attitude leads to the conclusion that in the future the younger generation may be more loyal to nuclear energy, which will increase the pace of its development around the world.

\section{CONCLUSIONS}

In general, the results show that the younger generation of both countries is quite loyal to nuclear power: many understand its prospects in the energy sector and objectively assess the possibility of risks. Despite this, Italian students do not support the idea of building and renewing the use of nuclear energy in Italy, which is an element of public opposition to the whole idea of the development of nuclear energy. Meanwhile, public approval in such matters plays a key role, since it contributes to the formation of the necessary understanding of the use of certain technologies.

\section{ACKNOWLEDGEMENT}

This research was supported by Act 211 Government of the Russian Federation, contract № 02.A03.21.0006.

\section{REFERENCES}

[1] Rada, E.C., Special waste valorization and renewable energy generation under a circular economy: Which priorities? WIT Transactions on Ecology and the Environment, vol. 222, WIT Press: Southampton and Boston, pp. 145-157, 2018.

[2] Gitelman, L., Magaril, E., Kozhevnikov, M. \& Rada E.C., Rational behavior of an enterprise in the energy market in a circular economy. Resources, 11(7), p. 2165, 2019.

[3] European Environment Agency. Nuclear Waste Production, 2018. http://themes.eea.europa.eu/Sectorsandactivities/energy/indicators/EN13. Accessed on: 14 Apr. 2019.

[4] Hubbel, M.W., The Fundamentals of Nuclear Power Generation: Questions \& Answers, AuthorHouse: Bloomington, 2011.

[5] Kyne, D., Nuclear Power Plant Emergencies in the USA: Managing Risks, Demographics and Response, Springer International Publishing AG: Switzerland, 2017.

[6] Georgios, K.P \&, Dimitrios, N. (eds), Nuclear Power Plants, Nova Science Publishers: New York, 2011.

[7] Budnitz, R.J., Rogner, H.-H. \& Shihab-Eldin, A., Expansion of nuclear power technology to new countries: SMRs, safety culture issues, and the need for an improved international safety regime. Energy Policy, 119, pp. 535-544, 2018.

[8] Renewable Resources Coalition. Nuclear Energy: Pros and Cons, 2018. www.renewableresourcescoalition.org/nuclear-energy-pros-cons/. Accessed on: 15 May 2019.

[9] Antaki, G. \& Gilada, R., Nuclear Power Plant Safety and Mechanical Integrity: Design and Operability of Mechanical Systems, Equipment and Supporting Structures, Elsevier: New York, 2015.

[10] Alam, F., Sarkar, R. \& Chowdhury, H., Nuclear power plants in emerging economies and human resource development: A review. Energy Procedia, 160, pp. 3-10, 2019.

[11] Verbruggen, A., Laes, E. \& Lemmens, S., Assessment of the actual sustainability of nuclear fission power. Renewable and Sustainable Energy Reviews, 32, pp. 16-28, 2014. 
[12] Hugo, V.J. \& Gertman, D.I., A method to select human-system interfaces for nuclear power plants. Nuclear Engineering and Technology, 48, pp. 89-97, 2016.

[13] Siegrist, M., Keller, C. \& Cousin, M.E., Implicit attitudes toward nuclear power and mobile phone base stations: Support for the affect heuristic. Risk Analysis, 26, pp. 1021-1029, 2006.

[14] Arikawa, H., Cao, Y. \& Matsumoto, S., Attitudes toward nuclear power and energysaving behaviour among Japanese households. Energy Research and Social Science, 2, pp. 12-20, 2014.

[15] World Nuclear Association, Nuclear Power in The USA (updated in April 2019). www.world-nuclear.org/information-library/country-profiles/countries-t-z/usanuclear-power.aspx. Accessed on: 31 Mar. 2019.

[16] Assefa, G. \& Frostell, B., Social sustainability and social acceptance in technology assessment: a case study of energy technologies. Technology in Society, 29(1), pp. 63$78,2007$.

[17] Geng, L., Liu, T., Zhou, K. \& Yang, G., Can power affect environmental risk attitude toward nuclear energy? Energy Policy, 113, pp. 87-93, 2018.

[18] Lammers, J., Galinsky, A.D., Gordijn, E.H. \& Otten, S., Power increases social distance. Social Psychological and Personality Science, 3(3), pp. 282-290, 2012.

[19] Magee, J.C. \& Galinsky, A.D., 8 social hierarchy: The self-reinforcing nature of power and status. The Academy of Management Annals, 2(1), pp. 351-398, 2008.

[20] European Environment Agency, Italy GHG and Energy 2017 Country Profile, 2017. www.eea.europa.eu/themes/climate/trends-and-projections-in-europe/trends-andprojections-in-europe-2017/country-profiles-greenhouse-gases-and-energy/italy-ghgand-energy-country-profile.pdf/view.

[21] World Nuclear Association, Nuclear Power in Russia, 2018. www.world-nuclear.org/ information-library/country-profiles/countries-o-s/russia-nuclear-power.aspx.

Accessed on: 5 Apr. 2019.

[22] Quora, Is BN-800 the Best Nuclear Reactor For Now? 2007. www.quora.com/Is-BN800-the-best-nuclear-reactor-for-now. Accessed on: 15 May 2019.

[23] World Nuclear Association, Nuclear Power in Italy, 2018. www.world-nuclear.org/ information-library/country-profiles/countries-g-n/italy.aspx. Accessed on: 6 Apr. 2019.

[24] Radiation Emergency Medical Management, U.S. Department of Health and Human Services, Personal Protective Equipment (PPE) in a Radiation Emergency. www.remm.nlm.gov/radiation_ppe.htm. Accessed on: 9 Apr. 2019.

[25] Tsilikis, I., Pantos, I., Zouliati, I., Koutra, A., Kalinterakis, G. \& Syllaios, A., Radiological risks from potential exposure of the population to radiation from orphan radioactive sources. Health Physics, 116(5), pp. 715-719, 2019.

[26] Stoutenborough, W.J., Shelbi, G., Sturgess, G.S. \& Vedlitz, A., Knowledge, risk and policy support: Public perception of nuclear power. Energy Policy, 62, pp. 176-184, 2013.

[27] Huang, L., Zhou, Y., Han, Y., Hammitt, J.K., Bi, J. \& Liu, Y., Effect of the Fukushima nuclear accident on the risk perception of residents near a nuclear power plant in China. Proceedings of the National Academy of Sciences of the USA, 110(49), pp. 1972-1974, 2013. 